Lithospheric structure, composition, and thermal regime of the East European craton Implications for the subsidence of the Russian Platform

Artemieva, Irina

Published in:

Earth and Planetary Science Letters

Publication date:

2003

Document version

Early version, also known as pre-print

Citation for published version (APA):

Artemieva, I. (2003). Lithospheric structure, composition, and thermal regime of the East European craton:

Implications for the subsidence of the Russian Platform. Earth and Planetary Science Letters, 213, 429-444. 


\title{
Lithospheric structure, composition, and thermal regime of the East European Craton: implications for the subsidence of the Russian platform
}

\author{
Irina M. Artemieva ${ }^{\mathrm{a}, \mathrm{b}, *}$ \\ a EOST, 5 rue Rene Descartes, Strasbourg 67084, France \\ b USGS, MS 977, 345 Middlefield Road, Menlo Park, CA 94025, USA
}

Received 22 November 2002; received in revised form 1 April 2003; accepted 2 June 2003

\begin{abstract}
A new mechanism for Paleozoic subsidence of the Russian, or East European, platform is suggested, since a model of lithosphere tilting during the Uralian subduction does not explain the post-Uralian sedimentation record. Alternatively, I propose that the Proterozoic and Paleozoic rifting (when a platform-scale Central Russia rift system and a set of Paleozoic rifts were formed) modified the structure and composition of cratonic lithosphere, and these tectono-magmatic events are responsible for the post-Uralian subsidence of the Russian platform. To support this hypothesis, (a) the thermal regime and the thickness of the lithosphere are analyzed, and (b) lithospheric density variations of non-thermal origin are calculated from free-board constraints. The results indicate that Proterozoic and Paleozoic rifting had different effects on the lithospheric structure and composition. (1) Proterozoic rifting is not reflected in the present thermal regime and did not cause significant lithosphere thinning (most of the Russian platform has lithospheric thickness of 150-180 km and the lithosphere of the NE Baltic Shield is 250-300 km thick). Paleozoic rifting resulted in pronounced lithospheric thinning (to 120-140 km) in the southern parts of the Russian platform. (2) Lithospheric density anomalies suggest that Proterozoic-Paleozoic rifting played an important role in the platform subsidence. The lithospheric mantle of the Archean-early Proterozoic part of the Baltic Shield is $\sim 1.4 \pm 0.2 \%$ less dense than the typical Phanerozoic upper mantle. However, the density deficit in the subcrustal lithosphere of most of the Russian platform is only about $(0.4-0.8) \pm 0.2 \%$ and decreases southwards to $\sim 0 \%$. Increased densities (likely associated with low depletion values) in the Russian platform suggest strong metasomatism of the cratonic lithosphere during rifting events, which led to its subsidence. It is proposed that only the lower part of the cratonic lithosphere was metasomatized as a result of Proterozoic rifting; the boundary between a depleted upper and more fertile lower layers can be at ca. $90-150 \mathrm{~km}$ depth and can produce a seismic pattern similar to the top of a seismic low-velocity zone. Paleozoic rifting has modified the entire lithospheric column and the regions affected are still subsiding.

Published by Elsevier B.V.
\end{abstract}

Keywords: craton; East European platform; lithosphere; crust; geotherms; depletion; rifting; subsidence

* Fax: +33-3-9024-0125.

E-mail address: irina@eost.u-strasbg.fr (I.M. Artemieva).

\section{Introduction}

The East European Craton (EEC) comprises 

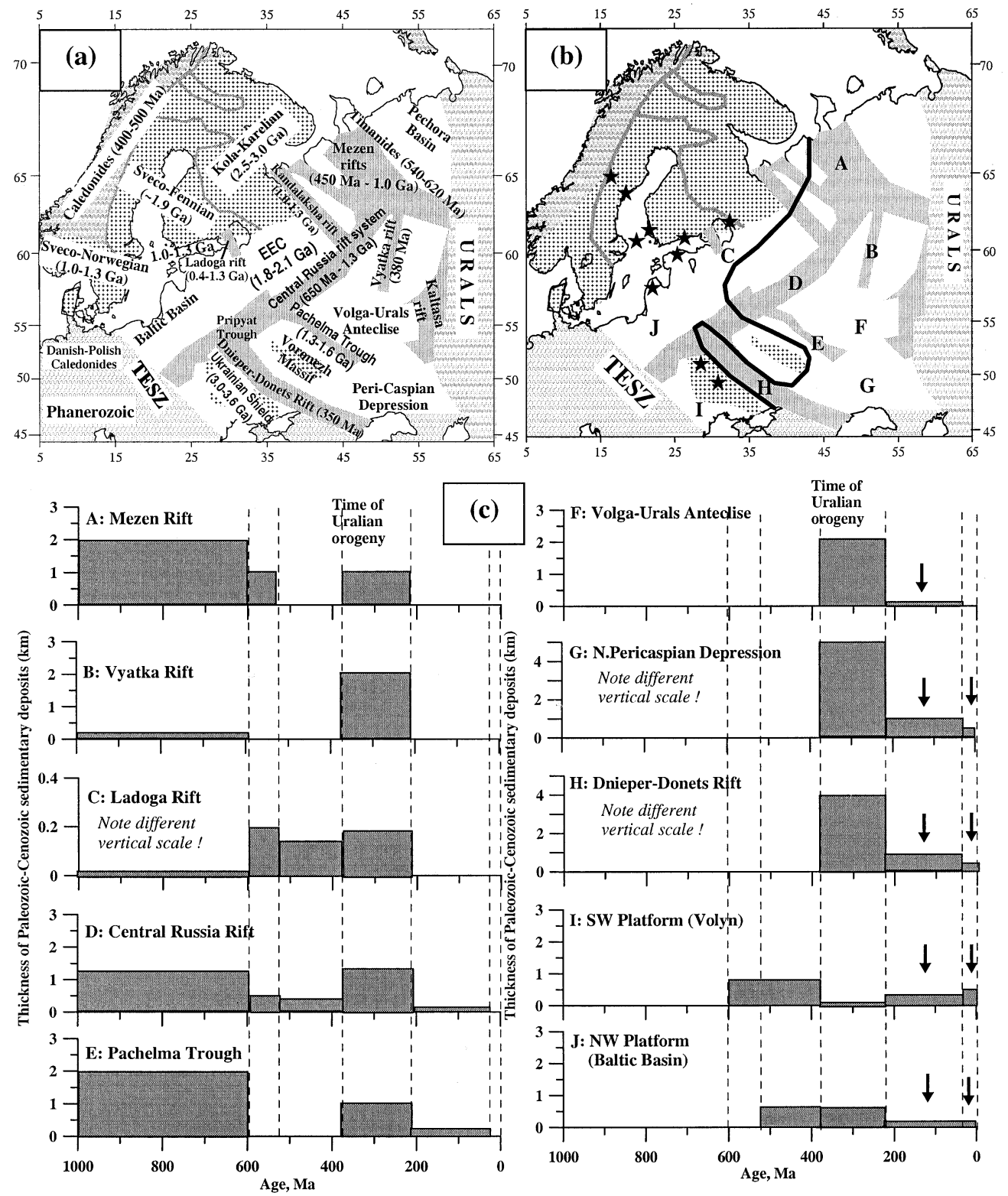

Fig. 1. Tectonic and subsidence history of the EEC. (a) Major tectonic units of the EEC and their tectono-thermal ages. Location and ages of Riphean-Devonian rifts in the EEC after [1,3]. (b) The location of 10 areas (A-J) chosen for a comparison of sedimentation history. They include Precambrian rifts (A-E) and regions where sedimentation did not start until Paleozoic (F-J). Area I - the Volyn flood basalts province ( 650-570 Ma, [2]). Black line shows the western border of the area where more than $500 \mathrm{~m}$ of sediments were deposited at 375-215 Ma (after [3]). Stars show locations of rapakivi-anorthosite complexes (with the ages of 1.50-1.65 Ga in the Baltic Shield and 1.72-1.79 Ga in the Ukrainian Shield) (after [70]). (c) Thickness of sediments deposited in different parts of the Russian platform in Proterozoic to Cenozoic. Data on sedimentation record has been adopted from isopach maps of [3] for six time intervals. Note a peak in sedimentation at 375-215 Ma, synchronous over the entire Russian platform and related to the Uralian orogeny [7]. Southern parts of the platform affected by Paleozoic rifting (F-I) continue to subside even in post-Uralian time. This pattern is not observed in Proterozoic rifts. A model other than lithospheric tilting over a subducting slab is required to explain the post-Uralian subsidence. 
lithospheric provinces ranging in age from Archean to late Proterozoic (Fig. 1a); most of the Russian, or East European, platform is early Proterozoic. A large part of the EEC has undergone intensive rifting in Proterozoic and Paleozoic time. The fundamental trans-cratonic lithospheric weakness zone, the Central Russia rift system, was formed $\sim 1.3-1.0 \mathrm{Ga}$; a large part of it was affected by intraplate volcanism at $\sim 1.0 \mathrm{Ga}-650$ Ma. However, for not yet understood reasons the post-rift subsidence did not start until $\sim 600 \mathrm{Ma}$ [1]. The southern parts of the Russian platform were rifted in the Devonian (with the latest peak of activity at $\sim 350 \mathrm{Ma}[1]$ ) when an extensive system of rifts, including the Pripyat-Dnieper-Donets rift, was formed. A large volume of rift-related magmatism suggests a plume origin [2].

The most obvious physiographic characteristic of the EEC is the existence of the vast 3-km-thick sedimentary cover over the ca. 3000-km-wide platform area, which is in sharp contrast to the exposed basement of the Baltic Shield.

The subsidence history of the Russian platform from late Riphean to present (Fig. 1c) has been summarized on the basis of lithological-paleogeographical maps of the USSR [3]. Numerical models of viscous flow in the mantle predict that subducting slabs can cause subsidence of 1000-kmwide areas within continental interiors; the resultant topographic deflections can persist for 100 $150 \mathrm{Ma}$ [4-6]. Mitrovica et al. [7] used this idea to explain a rapid downwarping episode at 375-215 Ma, nearly synchronous over the whole Russian platform, by a dynamic response of the cratonic lithosphere to the westward dipping subduction beneath the Urals. The model prediction of topographic deflections is in agreement with the Devonian to Permian sedimentation record. However, the model cannot explain the post-Uralian, still on-going, subsidence of the southern parts of the Russian platform (Fig. 1c, areas F-I). Moreover, the pattern of subsidence has significantly changed at ca. $215 \mathrm{Ma}$ [3]: the thickness of the sediments deposited during the Uralian orogeny decreases westwards from the Urals, while the thickness of younger sediments shows a clear tendency to increase southwards (Fig. 1b and Section 4.3.2).
The high topography of Archean-early Proterozoic cratons is commonly attributed to depleted, low-density composition of their lithospheric mantle (e.g. [8]). Rifting, however, leads to density increase of the cratonic lithosphere due to intrusion of Fe-rich basaltic melts [9] and can be responsible not only for subsidence due to thermal relaxation after the end of thermo-magmatic events, but also for compositional subsidence.

In order to explain the subsidence of the Russian platform, and especially the post-Uralian episode, I estimate the average density of the lithospheric mantle of the EEC and conclude that the platform subsidence can indeed result from chemical variations in the lithospheric mantle, possibly caused by metasomatism during Proterozoic and Paleozoic rifting.

\section{Tectonic history as reflected in the crustal structure of the EEC}

The crustal structure of the EEC is well studied by numerous seismic reflection and refraction profiles (some of the important ones include [10-19]). These models are summarized in the global USGS database on the crustal structure [20]. No simple correlation between the crustal thickness and surface geology can be found for the EEC, except that both of the shields (i.e. the Baltic and the Ukrainian) are characterized by the thickest crust $(>50 \mathrm{~km})$, while the crustal thickness within most of the Russian platform is $\sim 40$ $45 \mathrm{~km}$.

The pattern, however, becomes noteworthy, if one looks at the thicknesses of the individual crustal layers (for simplicity defined here by seismic velocities: $5.8<V_{\mathrm{p}}<6.4 \mathrm{~km} / \mathrm{s}$ for the upper crust; $6.4<V_{\mathrm{p}}<6.8 \mathrm{~km} /$ for the middle crust; $6.8<V_{\mathrm{p}}<7.6 \mathrm{~km} / \mathrm{s}$ for the lower crust). The thickest lower crust $(>20 \mathrm{~km})$ exists beneath the Archean Ukrainian Shield and the Archeanearly Proterozoic Finnish-Kola-Karelian part of the Baltic Shield, and can be a result of extensive terrane accretion, re-assemblage, collision, or underplating by buoyantly subducted slabs in the early Precambrian time (e.g. [21-23]). 
Statistical analysis of the global USGS crustal database [20] shows that the thickness of the upper and middle crust within the Russian platform is surprisingly well correlated with the position of the Proterozoic Central Russia rift system (including the Pachelma Trough), where upper crustal thickness increases to $16 \mathrm{~km}$ and more, and is accompanied by an almost complete disappearance of the middle crust (typically less than $4 \mathrm{~km}$ thick). Similar results were reported for several seismic profiles crossing Proterozoic rifts of the Russian platform [24]. The observed variations in the thickness of the crustal layers are interpreted here to result from Proterozoic tectonomagmatic processes, which could have led to an increase of the upper crustal thickness by magmatic additions and 'squeezing out' of the ductile middle crust (for more discussion see Section 4.3 and Fig. 5).

Correlation between the crustal structure of the EEC and its tectonic history implies that the mantle processes responsible for the formation and modification of the crust should have also affected the structure of the entire lithospheric column. On one hand, one could expect that Proterozoic-Paleozoic rifting resulted in thinning of the lithosphere of the Russian platform. On the other hand, petrologic data indicate that an interaction of upwelling asthenospheric material with a cratonic root results in lithospheric metasomatism and/or its replacement by younger, more fertile, and more dense mantle (e.g. $[25,26]$ ).

Seeking the answer to the question how the thickness and composition of the cratonic lithosphere is affected by rifting, I examine the thermal regime of the lithosphere of the EEC and use freeboard constraints to calculate variations of lithospheric density of non-thermal origin. I focus the attention on (1) the central part of the Russian platform, rifted in Proterozoic, and (2) the southern part of the Russian platform, rifted in Paleozoic, and compare them with the Archeanearly Proterozoic regions of the Baltic Shield. As the geological age of the Russian platform is also early Proterozoic, such a comparison permits us to examine the effects of rifting on the structure and composition of the cratonic lithosphere.

\section{Thermal regime of the EEC and lithospheric thickness}

\subsection{Heat flow data}

Most of thermal models published for the EEC are based on a continent-scale or global-scale studies [27-29], or on regional models (e.g. [3035]). Here a thermal model for the entire EEC is presented, following the constraints of [29].

Reliable surface heat flow data for the EEC (Fig. 2a,b) derived from [36-37] formed the basis for the calculation of lithospheric geotherms. Chiefly measurements from deep boreholes are used in the study. The original heat flow data for the entire EEC has been corrected for paleoclimatic disturbances using the standard procedures; the paleoclimatic corrections to the surface heat flow do not exceed $10 \%[30,33,38]$.

Almost no correlation exists between geologic provinces of the EEC and the surface heat flow, although the transition from the cratonic lithosphere to the lithosphere of western Europe is marked by a pronounced heat flow increase of more than $20 \mathrm{~mW} / \mathrm{m}^{2}$ (Fig. 2a). Within the craton, the lowest heat flow values $\left(<30 \mathrm{~mW} / \mathrm{m}^{2}\right)$ are measured in the Finnish-Karelian Province of the Baltic Shield. The rest of the EEC has surface heat flow typical for Archean-early Proterozoic cratons, 35-45 $\mathrm{mW} / \mathrm{m}^{2}$ (e.g. [39]), with slightly higher values $\left(40-55 \mathrm{~mW} / \mathrm{m}^{2}\right)$ in the southern part of the craton. However, locally the heat flow exceeds $70 \mathrm{~mW} / \mathrm{m}^{2}$ (e.g. in the Pripyat Trough).

\subsection{Calculation of lithospheric geotherms}

Most of the EEC has not experienced a major tectonic event since the end of the Precambrian; therefore the thermal structure of the lithosphere can be approximated by the steady-state solution of the thermal conductivity equation. This approximation is also valid for the parts of the Russian platform, affected by Paleozoic rifting, where thermal equilibrium is expected to be re-established. Thermal anomaly associated with Paleozoic rifting is reflected in the present surface heat flow, since thermal perturbation at the base of 

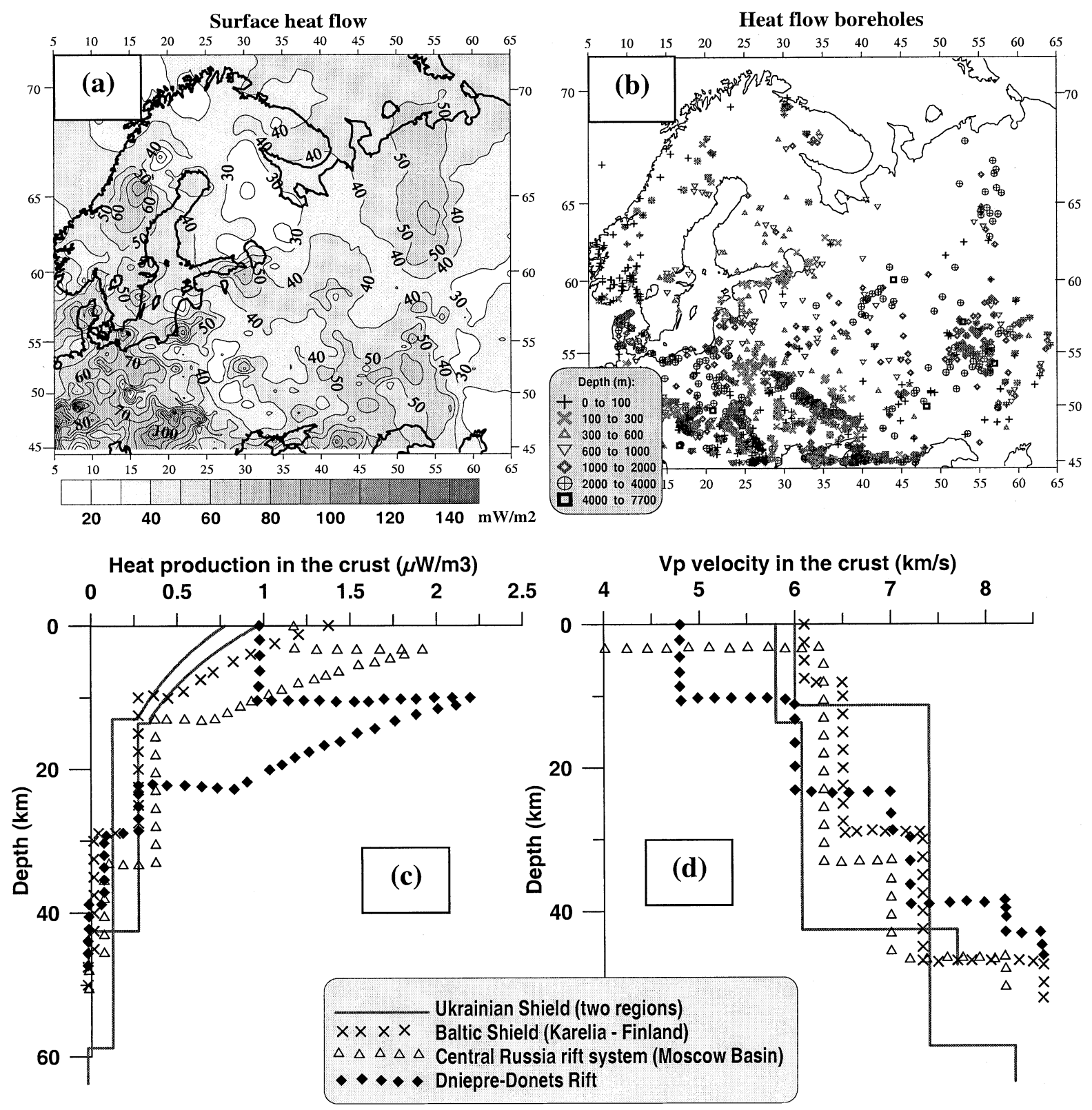

Fig. 2. Heat flow and crustal heat production for the EEC. (a) Surface heat flow in the EEC; (b) location and depth of heat flow boreholes; examples of crustal heat production models (c) based on $V_{\mathrm{p}}$ seismic velocities (d) for different regions.

the lithosphere with a thickness of $\sim 150-200 \mathrm{~km}$ reaches the surface in ca. 250-350 Ma.

In this study, models of depth distribution of thermal parameters are constrained for about 70 tectonic blocks within the EEC from seismic mea- surements of the crustal structure (derived from the global USGS database [20]). Values of heat production and thermal conductivity in sediments and in the shallow upper crust are based on regional laboratory measurements on surface and 
borehole rocks (e.g. [40,41]). In the present study, the upper, middle, and lower crusts are defined by seismic velocities; heat production in the crustal layers is assigned to be $0.5-3.7 \mu \mathrm{W} / \mathrm{m}^{3}, 0.3-0.7$ $\mu \mathrm{W} / \mathrm{m}^{3}$, and $0.1-0.4 \mu \mathrm{W} / \mathrm{m}^{3}$, respectively; the corresponding values of conductivity in three crustal layers are $2.5-3.0 \mathrm{~W} / \mathrm{m} / \mathrm{K}, 2.0-2.5 \mathrm{~W} / \mathrm{m} / \mathrm{K}$, and $2.0 \mathrm{~W} / \mathrm{m} / \mathrm{K}$. Heat production in the upper part of the basement $(5-16 \mathrm{~km})$ is assumed to decrease exponentially with depth. For the lithospheric mantle, thermal conductivity is $4.0 \mathrm{~W} / \mathrm{m} / \mathrm{K}$ and the value of heat production is $0.01 \mu \mathrm{W} / \mathrm{m}^{3}$ below Moho and $0.004 \mu \mathrm{W} / \mathrm{m}^{3}$ for $V_{\mathrm{p}}>8.3 \mathrm{~km} / \mathrm{s}$. For a detailed discussion of the choice of model parameters the reader is referred to [29].

Examples of crustal heat production models based on regional seismic velocity structure (Fig. 2d) are shown in Fig. 2c for five areas of the EEC. Total average crustal heat production estimated for different regions of the EEC increases from Archean to Proterozoic terranes (with the corresponding values of $0.36-0.50 \mu \mathrm{W} / \mathrm{m}^{3}$ and 0.44 $0.83 \mu \mathrm{W} / \mathrm{m}^{3}$ ); however insufficient data does not permit us to find any correlations with tectonic structures of the Russian platform.

\subsection{Moho temperatures}

Lithospheric geotherms in the EEC (Fig. 3) are constrained here by 1D thermal modeling since in large parts of the craton either surface heat flow data (Fig. 2b) or detailed data on the crustal structure are absent. This approximation is valid only when applied to long-wavelength thermal anomalies, when horizontal diffusion of heat flux can be neglected. Heat flow anomalies of the shortest wavelength $(\sim 150-200 \mathrm{~km})$ are observed in the western parts of the craton (especially within the Ukrainian Shield) implying that their source is within the upper $60-70 \mathrm{~km}$ of the lithosphere [42] and that they are caused primarily by variations in the crustal heat production. However, for most of the Russian platform, the wavelength of surface heat flow anomalies is about $300-500 \mathrm{~km}$ and their origin should be deeper than $150-200 \mathrm{~km}$.

Temperatures at the base of the crust and in the upper mantle of the EEC show a strong corre- lation with tectonic setting (Fig. 3a,b). Within the Baltic Shield, Moho temperatures vary from $\sim 350$ to $450^{\circ} \mathrm{C}$ in the Archean-early Proterozoic Finnish-Kola-Karelian Province, through 500 $700^{\circ} \mathrm{C}$ in the early Proterozoic Sveco-Fennian Province, to $600-700^{\circ} \mathrm{C}$ in the middle Proterozoic Sveco-Norwegian Province and the Caledonides.

Within the central Russian platform, temperatures at the base of the crust are similar to the early Proterozoic part of the Baltic Shield (450$600^{\circ} \mathrm{C}$ ), with slightly higher Moho temperatures along the Central Russia rift system. However, the difference is not sufficiently pronounced to imply a large-scale thermal anomaly in the mantle, which could have explained the thermal subsidence of the platform. There is, however, a pronounced increase in Moho temperature in the southern parts of the Russian platform (550 $700^{\circ} \mathrm{C}$ ), which were rifted in Devonian.

\subsection{Heat flow at the lithospheric base}

A pronounced correlation between the mantle thermal regime of the EEC and the tectono-thermal age of the lithosphere is clearly seen in the values of the mantle heat flow (Fig. 3c). The lowest values $\left(\sim 16-18 \mathrm{~mW} / \mathrm{m}^{2}\right)$ are calculated for the Archean-early Proterozoic Finnish-Karelian Province, assuming a lower crustal heat production (A) of $0.1 \mu \mathrm{W} / \mathrm{m}^{3}$ (this parameter is one of the most poorly constrained in geothermal models, see [29] for a discussion). Similar results were obtained by Pasquale et al. [32] for the Baltic Shield for the same value of lower crustal heat production. For another commonly accepted value of $0.4 \mu \mathrm{W} / \mathrm{m}^{3}$ and a thickness of the lower crust of $16 \mathrm{~km}$ and more, mantle heat flow in this part of the Baltic Shield is $\sim 11-13 \mathrm{~mW} / \mathrm{m}^{2}$, which is in a good agreement with xenolith data $\left(11 \pm 4 \mathrm{~mW} / \mathrm{m}^{2}\right)$ [31]. Mantle heat flow in the Ukrainian Shield and in most of the Russian platform is $\sim 20-22 \mathrm{~mW} / \mathrm{m}^{2}$ for $A=0.1 \mu \mathrm{W} / \mathrm{m}^{3}$ in the lower crust (or, assuming $A=0.4 \mu \mathrm{W} / \mathrm{m}^{3}$ and accounting for regional variations in thickness of the lower crust in the EEC, $\sim 12 \mathrm{~mW} / \mathrm{m}^{2}$ for the Ukrainian Shield and $\sim 18 \mathrm{~mW} / \mathrm{m}^{2}$ for most of the Russian platform). 

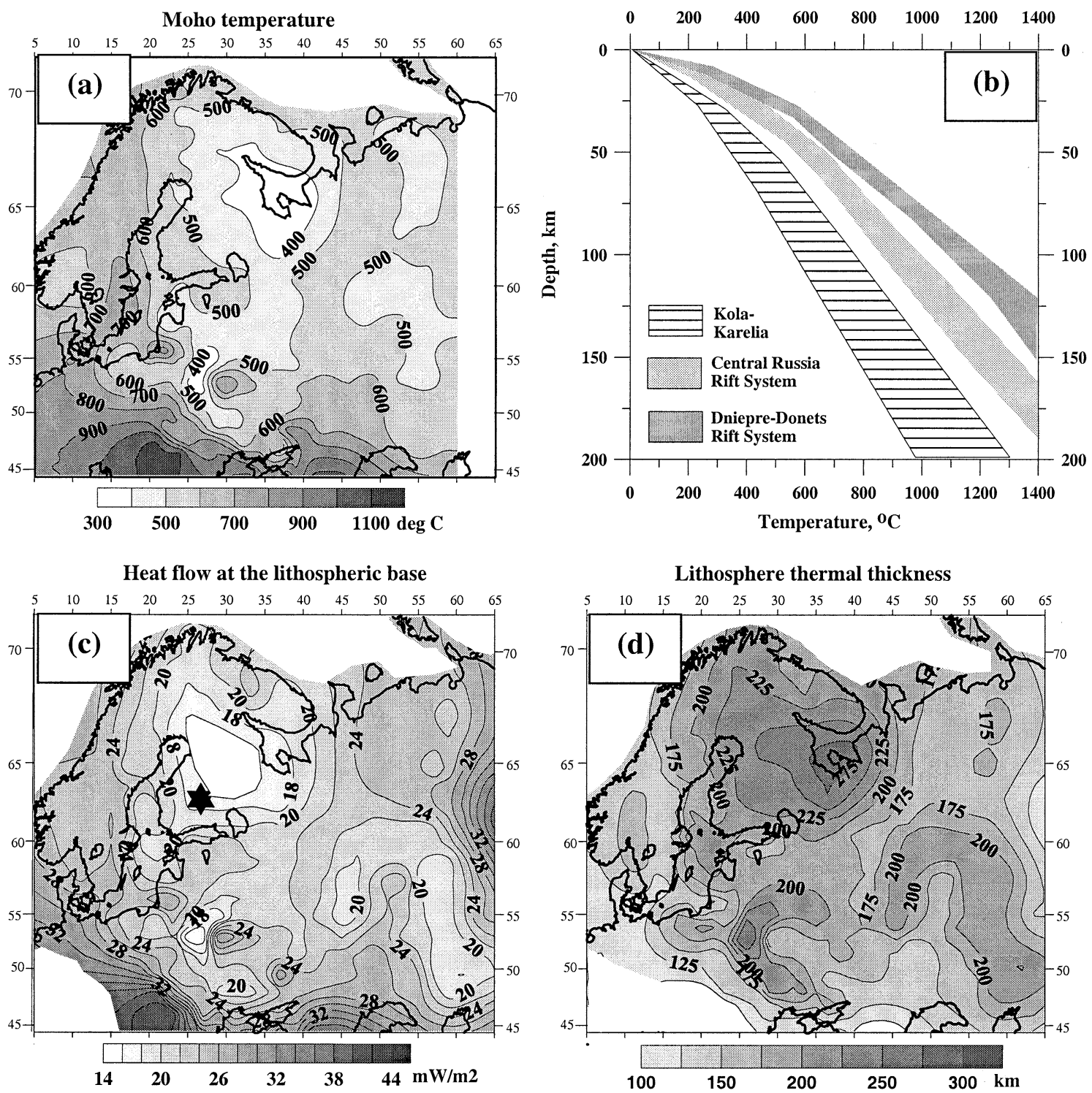

Fig. 3. Thermal regime of the EEC. (a) Moho temperatures in the EEC (the uncertainty is ca. $50^{\circ} \mathrm{C}$ ). (b) Geotherms calculated for the Russian platform and the Baltic Shield. Paleozoic rifts have higher geotherms than Proterozoic rifts and the shields. (c) Mantle heat flow calculated from heat flow data for a lower crustal heat production $A=0.1 \mu \mathrm{W} / \mathrm{m}^{3}$. If $A=0.4 \mu \mathrm{W} / \mathrm{m}^{3}$ in the lower crust, mantle heat flow in the Karelian Province would be $\sim 12 \mathrm{~mW} / \mathrm{m}^{2}$. The star marks the kimberlite location in the Karelian Province, for which the xenolith geotherm [31] suggests a mantle heat flow of $11 \pm 4 \mathrm{~mW} / \mathrm{m}^{2}$. (d) Lithosphere thermal thickness as the depth to $1300^{\circ} \mathrm{C}$ mantle adiabat (the uncertainty is ca. $\pm 25 \mathrm{~km}$ ). Lithospheric thickness in the EEC is $160-180 \mathrm{~km}$ along the Proterozoic-Paleozoic intracratonic rifts, $180-210 \mathrm{~km}$ elsewhere in the Russian platform and in the Ukrainian Shield. The highest values $(250-300 \mathrm{~km})$ are found for the Finnish-Kola-Karelian Province of the Baltic Shield.

\subsection{Lithospheric thickness}

The largest values of lithospheric thickness (defined as the depth to the mantle adiabat of $\left.1300^{\circ} \mathrm{C}\right)$ within the EEC $(250-300 \mathrm{~km})$ are found for the Finnish-Kola-Karelian region of the Baltic Shield (Fig. 3d). Thermal estimates are in agreement with recent seismic surface-wave interpreta- 
tions [43], which show $>1 \% V_{\mathrm{s}}$ velocity anomaly down to at least $300 \mathrm{~km}$ depth. Surprisingly, the Ukrainian Shield, which has even older geological age, has a much thinner lithosphere, thickest $(\sim 200-220 \mathrm{~km})$ in the north-central parts and thinnest $(\sim 170 \mathrm{~km})$ in the southeastern part of the Ukrainian Shield (Fig. 3d). Large variations in lithospheric thickness within the Ukrainian Shield reflect its block structure identified from surface geology, and suggest that individual terranes within the shield could have preserved their own lithospheric roots since the assembly of the Archean craton. Xenolith data from Siberia indicate that such situation is not unique. Differences in bulk composition of the lithospheric mantle and xenolith geotherms imply that different crustal terranes of the Siberian Craton have preserved individual lithospheric roots since their formation and Proterozoic cratonization [44].

We further focus on the parts of the Russian platform, affected by Proterozoic and Paleozoic rifting. Similarly to the early Proterozoic regions of the Baltic Shield, most of the Russian platform has a lithospheric thermal thickness of $\sim 180-210$ $\mathrm{km}$ with only slightly smaller values along the Central Russia rift system (160-180 km) (Fig. $3 \mathrm{~d})$. These values are well within the range of lithospheric thickness estimates for other early Proterozoic terranes of the world [29]. For example, within the Baltic Shield, the Sveco-Fennian Province of similar age has lithospheric thickness of $\sim 150-200 \mathrm{~km}$. These results indicate that Proterozoic rifting of the EEC is almost non-reflected in its present thermal regime and lithospheric thickness, and that the post-rifting Paleozoic and Mesozoic subsidence of the Central Russian platform [3] is unlikely to be attributed solely to thermal cooling and lithosphere thermal thinning.

In the southern parts of the Russian platform, lithospheric thickness decreases to $\sim 120-140 \mathrm{~km}$, which is ca. $60 \mathrm{~km}$ less than expected for early Proterozoic cratons. Such values are typical for middle-late Proterozoic terranes, e.g. the SvecoNorwegian Province of the Baltic Shield. Small lithospheric thickness in the southern part of the Russian platform implies that Paleozoic thermomagmatic events, probably associated with a mantle plume [2], had a strong effect on the cra- tonic keel. The difference in the thermal regime of the lithosphere of the largely Proterozoic Central Russia rift system and the Paleozoic rifts of the southern Russian platform is clearly seen from lithospheric geotherms (Fig. 3b).

The results suggest that Proterozoic and Paleozoic rifting might have affected the cratonic keel in different ways. We next examine if these thermo-magmatic events have changed lithospheric buoyancy since mechanisms other than thermal are required to explain why the huge area of the North-Central Russian platform has subsided since late Proterozoic and why the southern parts of the platform continue to subside since the Devonian rifting. A compositional origin of subsidence provides an alternative explanation and this hypothesis is tested further by calculating average lithospheric density of different parts of the EEC.

\section{Density of the subcrustal lithosphere}

\subsection{Calculation of lithospheric buoyancy and depletion}

Temperatures at the base of the crust (Fig. 3a) and lithospheric thermal thickness values (Fig. 3d) together with data on surface topography and crustal structure permit estimation of density contrast between the asthenosphere and the lithospheric mantle. Density variations of thermal origin within the subcrustal lithosphere are taken into account from data on typical lithospheric geotherms for a thermal expansion coefficient for the subcrustal lithosphere of $3.5 \times 10^{-5} /{ }^{\circ} \mathrm{C}$. Following the approach of Lachenbruch and Morgan [45], it is assumed that isostatic balance is achieved locally at the base of the lithosphere. In this case, surface topography results from crustal buoyancy (which depends on crustal thickness and its average density) and subcrustal lithospheric buoyancy (which depends on lithospheric thickness, as estimated earlier, and its average density). Data on crustal structure (thickness and density) are derived from the CRUST 5.1 model [46] for $5^{\circ} \times 5^{\circ}$ cells. For consistency, all other data (Moho temperatures, lithospheric thickness, and 
surface topography derived from the ETOPO2 database [47]) are also averaged to $5^{\circ} \times 5^{\circ}$ cells.

Fig. 4a shows the total compositional density deficit within the entire vertical column of the subcrustal lithosphere of the EEC, as compared to asthenospheric density, assumed here to be 3.39 $\mathrm{g} / \mathrm{cm}^{-3}$ [48]. The approach does not allow speculating regarding how compositional anomalies are distributed with depth, nor to distinguish the processes responsible for lithospheric density variations. However, the results shown in Fig. 4a agree with calculations of lateral density variations in the lithospheric mantle, based on temperaturecorrected Bouguer gravity anomalies [49].

Lateral compositional density variations in the subcrustal lithosphere of the EEC are in the range from 0.0 to $-1.6 \%$, with the minimal value (corresponding to the strongest depletion) in the Baltic Sea. Positive values are calculated mostly for the Phanerozoic western Europe with the highest values (up to $+2.1 \%$ ) in the Alps. The possible origin of compositional lithospheric density anomalies is discussed below.

\subsection{Sensitivity analysis}

Lack of the detailed knowledge of the crustal structure and uneven coverage of heat flow measurements preclude the calculation of the errors of density variations in the lithospheric mantle. Instead, the sensitivity of the calculated mantle density anomalies to variations in different model parameters is evaluated in a set of test models. First, the effect of lithospheric thickness variations is estimated. A choice of $1100^{\circ} \mathrm{C}$ temperature as the base of the thermal lithosphere (which is equivalent to a $\sim 30-60 \mathrm{~km}$ thinner lithosphere than in Fig. 3d) leads to $<0.10 \%$ lower values of density deficit for the Baltic Shield and to $\sim 0.15 \%$ lower values for the rest of the Russian platform.

The effect of crustal density (which for $5^{\circ} \times 5^{\circ}$ cells varies from 2.78 to $2.93 \mathrm{~g} / \mathrm{cm}^{-3}$ with the average value of $2.87 \mathrm{~g} / \mathrm{cm}^{-3}$ ) on the calculated mantle densities is checked by a model with constant crustal density of $2.87 \mathrm{~g} / \mathrm{cm}^{-3}$ (but variable thickness). The largest difference between the basic (Fig. 4a) and the test model is for the Phaner- ozoic lithosphere of western Europe (up to $+0.8 \%$ ), while for the entire EEC the difference is between $-0.1 \%$ and $-0.2 \%$. A combined test shows that variations in both of model parameters reduce the values of the estimated lithospheric density deficit by about $0.25 \%$ for most of the Russian platform and by $\sim 0.4 \%$ for the SvecoFennian Province and the southwestern part of the EEC. In a further test the crust is assumed to be $2 \mathrm{~km}$ thicker (which is about the accuracy of crustal thickness estimates) than in the basic model. The resulting density anomalies in the EEC differ by less than $-0.03 \%$ from the basic model and do not exceed $0.1 \%$ for western Europe.

To summarize, the uncertainty in the calculated values of lithospheric density anomalies (Fig. 4a) does not exceed $\pm 0.30 \%$ in the EEC and typically is $\pm 0.15 \%$ to $\pm 0.20 \%$. For the Phanerozoic lithosphere the uncertainty can exceed the range of calculated density variations and thus western Europe is excluded from further discussion. There is one more parameter that is impossible to evaluate, i.e. the contribution of dynamic support to the observed topography. Its effect cannot be neglected in regions of active tectonics (e.g. [50]), like the Alps, but probably does not play a significant role for the EEC, except for the Caledonides.

\subsection{Compositional density variations in the lithospheric mantle of the EEC}

\subsubsection{Baltic Shield}

Density of the lithospheric mantle (at room temperature) calculated here for the early Precambrian $\left(\sim 3.33 \pm 0.01 \mathrm{~g} / \mathrm{cm}^{-3}\right)$ and for the Proterozoic $\left(\sim 3.35 \pm 0.01 \mathrm{~g} / \mathrm{cm}^{-3}\right)$ terranes of the Baltic Shield is at the high end of values derived from direct density measurements on low- $T$ peridotites from Archean roots [51,52] and from average densities calculated from mineral compositions for peridotites from Proterozoic mantle [48]. Such a systematic difference between buoyancy-based estimates and peridotite data may result from overestimated lithospheric temperatures used in the present modeling (Fig. 3b). Another possibility is undersampling of Fe-rich dunites (which have 

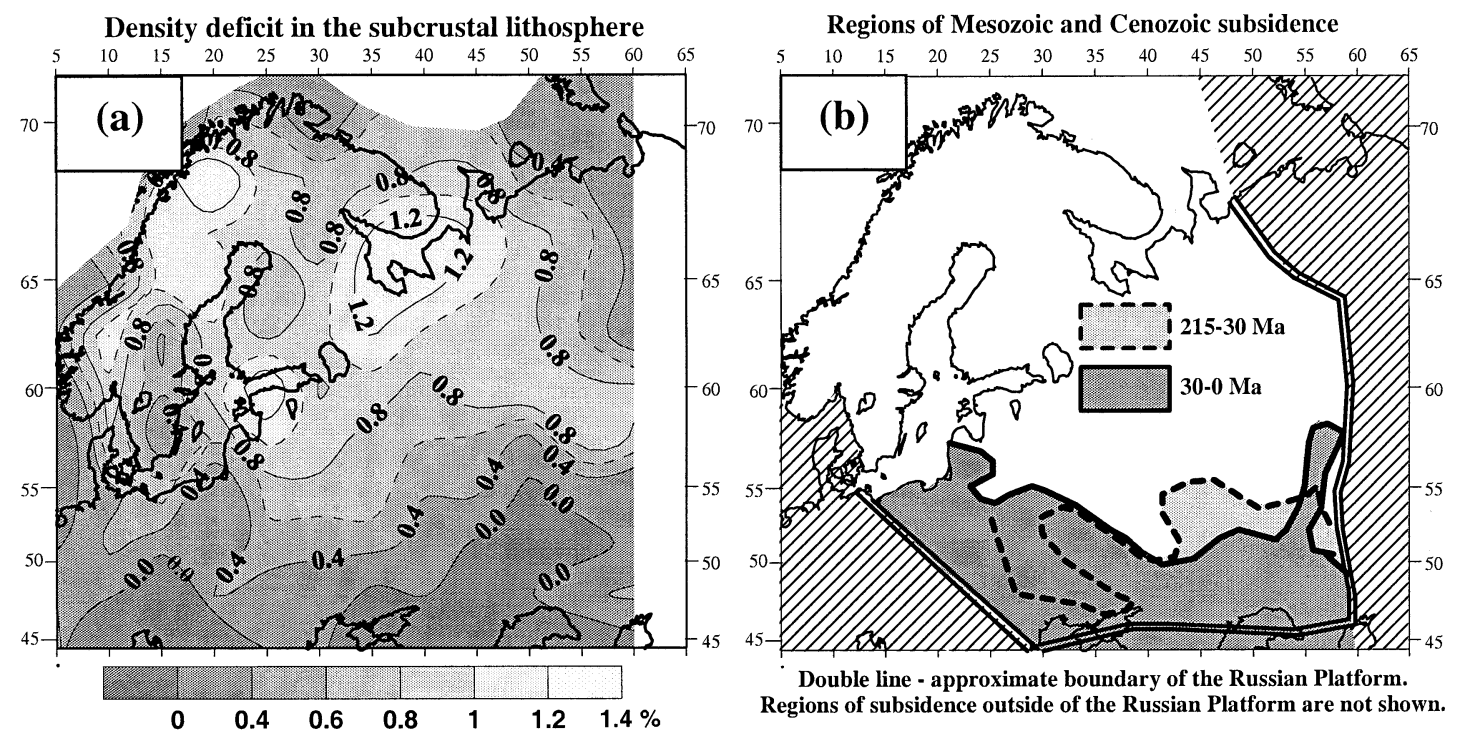

Fig. 4. Compositional density anomalies in subcrustal lithosphere of the EEC show a good correlation with areas of post-Uralian subsidence. Mantle lithosphere in the southern part of the Russian platform might have lost its lower depleted part due to metasomatism and partial erosion as a result of Paleozoic rifting. An increase of lithospheric density caused the post-Uralian, ongoing, subsidence of the southern part of the Russian platform. (a) Density deficit of non-thermal origin in subcrustal lithosphere calculated for $5 \times 5^{\circ}$ cells from Moho temperatures, lithospheric thickness (Fig. 3), crustal structure (derived from the CRUST 5.1 model), and topography (based on ETOPO2). For the EEC an uncertainty in density anomalies typically does not exceed $\pm 0.2 \%$. (b) Regions of the post-Uralian subsidence within the Russian platform (based on isopach maps of [3]). The dashed line and light gray shade show the area where more than $200 \mathrm{~m}$ of sediments were deposited at 215-30 Ma. The dark gray shade and solid line show the area which continues to subside in Cenozoic. Note a similarity between the border of the area of the post-Uralian subsidence and the contours of $0.4-0.6 \%$ of density deficit in the subcrustal lithosphere.

densities up to $3 \%$ greater than residual peridotites, [9]) by mantle xenoliths. Recent global analysis of lithospheric buoyancy [53] suggests that depletion of cratonic lithosphere may be indeed $\sim 0.5 \%$ less than indicated by xenolith data.

Mantle density is essentially controlled by olivine composition. A systemeatic decrease of forsterite content $(100 \mathrm{Mg} /(\mathrm{Mg}+\mathrm{Fe}))$ from Archean to younger lithospheric mantle suggests a strong secular increase of average density of the subcrustal lithosphere (e.g. [54-55]), observed in petrologic studies of mantle-derived peridotite xenoliths from different cratons [25,48,51]. The results for the Baltic Shield (Fig. 4a) show two strong lithospheric density anomalies: one with the maximum density deficit of $\sim 1.4 \%$ is centered at the White Sea and extends over the Archean Kola-Karelian Province. Surprisingly, the other anomaly with density deficit values up to $1.6 \%$ is located within the early Proterozoic Sveco-Fen- nian Province and is centered over the Finnish Bay of the Baltic Sea. Two regions with strong low-density anomalies are separated by the Paleozoic Ladoga rift (Fig. 1a). Paleozoic rifting may have locally modified the composition of this part of the cratonic mantle through metasomatism by Fe-enriched magmas, although regionally the lithosphere preserved thickness typical for the early Precambrian terranes. The lithospheric mantle of the rest of the Baltic Shield has a $\sim 0.8-1.0 \%$ density deficit, with larger values (up to $1.2 \%$ ) below the Caledonides, and smaller values $(\sim 0.5 \%)$ in the Sveco-Norwegian Province. Lowdensity values calculated for the Caledonides can result from an unaccounted dynamic topography associated with isostatic post-glacial relaxation (e.g. [56]). Thus, the results of this study show that, on the whole, for the Baltic Shield some correlation exists between density of the lithospheric mantle and the tectono-thermal age. 
Laboratory studies [57] indicate a strong effect of $\mathrm{Fe} /(\mathrm{Fe}+\mathrm{Mg})$ variations on seismic velocities; however, it is unclear to which extent they are masked by temperature anomalies in the upper mantle. Forte and Perry [58] argue that $V_{\mathrm{s}}$ anomalies alone are insufficient to distinguish chemical variations in the mantle. A recent analysis of the effect of temperature and iron content on seismic velocities [59] shows that a $1 \%$ velocity anomaly requires a $\mathrm{Fe}$ anomaly of $4 \%$ or a temperature anomaly of only $50^{\circ} \mathrm{C}$ (which is about the accuracy of thermal constraints at any lithospheric depth). Nevertheless, a comparison of lithospheric density anomalies (Fig. 4a) with seismic data for the Baltic Shield shows that the strong low-density anomaly of a non-thermal origin over the Finnish Bay (Baltic Sea) correlates with the strongest Rayleigh wave velocity anomaly in the upper $150 \mathrm{~km}$ [43] and a strong shear-wave attenuation anomaly in the upper $100 \mathrm{~km}$ of the lithosphere [60]. These anomalies do not correlate with a thermal anomaly (Fig. 3d), indicating that compositional variations in the mantle play an important role in producing seismic anomalies in the region. Furthermore, as a correlation between seismic velocity and attenuation models, on one hand, and density anomaly, on the other hand, does not hold at depths $>100-150 \mathrm{~km}$, one may speculate that the depletion anomaly in this part of the Baltic Shield is relatively shallow. A similar conclusion was made for the Kaapvaal and Tanzanian cratons, where studies of cratonic peridotites $[9,54]$ show that lithosphere depletion at shallow depth $(<150 \mathrm{~km})$ is much stronger than predicted by the isopycnic curve [61], while below $150 \mathrm{~km}$ depth density steeply increases to the asthenospheric value.

A shallow origin of the lithospheric density anomaly in the Baltic Sea region can be a result of Riphean (1.35-1.05 Ga) rifting. Magmatic activity, with emplacement of rapakivi granites (Fig. 1b) and subsequent subsidence of the basin might have resulted in a Fe-enrichment of the lower part of the cratonic lithosphere and even its detachment. Later lithospheric growth by thermal cooling might have created a two-layer lithosphere with more depleted upper and less depleted lower layers (see also Fig. 5). Relatively small volume of
Proterozoic magmatism in the Baltic region suggests that it was caused by a small-scale mantle convection rather than by a deep-seated mantle plume [62]. Thus, the lateral size of the compositional anomaly can be relatively small. Note, for example, that the Paleozoic Oslo graben is not resolved in the model (Fig. 4a).

The main region of a strong low-density anomaly in the Baltic Shield (Kola-Karelian Province) is of a particular interest. Calculations of lateral density variations in the lithospheric mantle, based on temperature-corrected Bouguer gravity anomalies ([49]; M. Kaban, personal communication, 2002), show the strongest anomaly over the same region, with the maximum density deficit values up to $2.4 \%$. It is unclear why this compositional anomaly is not reflected in seismic models at depths less than $150 \mathrm{~km}$, but it correlates well with the region of high $\mathrm{P}$-wave and Rayleigh wave velocities at a depth of $150-250 \mathrm{~km}$, indicating that the depleted cratonic lithosphere extends at least down to this depth. This conclusion agrees with petrologic data [63], which show that in most of the Archean cratons the mg\# of typical asthenospheric mantle is reached at a depth of 200-250 $\mathrm{km}$, interpreted as the base of the compositional lithosphere.

\subsubsection{Russian platform}

Lithospheric density anomalies of non-thermal origin, calculated for the Russian platform, are in a sharp contrast with the values for the FinnishKola-Karelian part of the Baltic Shield (Fig. 4a), despite similar geological ages of these two parts of the EEC. Average density of the subcrustal lithosphere progressively increases southwards from the Baltic Shield and reaches an asthenospheric value in the southern parts of the Russian platform. Nowhere within the Russian platform does lithospheric density show low values typical of early Proterozoic lithospheric mantle. Buoyancy requires that the subcrustal lithosphere of the central parts of the platform (including the Proterozoic Central Russia rift system) should be only $\sim 0.6-0.8 \%$ less dense than asthenosphere. Such density deficit is typical for the lithospheric mantle of middle and late Proterozoic age. Density deficit in the subcrustal lithosphere 
of the southern parts of the Russian platform, affected by intensive Devonian rifting, is less than $0.4 \%$ and is close to the values typical for Phanerozoic lithospheric mantle. Spatial correlation between the regions with high density of sublithospheric mantle (Fig. 4a) and the regions of the post-Uralian, on-going, subsidence in the southern part of the Russian platform (Fig. 4b) provides support for the hypothesis that the platform subsidence was caused by an increase of lithospheric density. Thus the results of this study imply that density variations in the subcrustal lithosphere of the EEC reflect the last major tectono-thermal event.

Metasomatic enrichment of the lithosphere during rifting results in a density increase due to formation of Fe-rich dunites and a loss of neutral buoyancy of the keels [9]. Much of the early Proterozoic lithospheric mantle of the Russian platform has been modified or even might have been

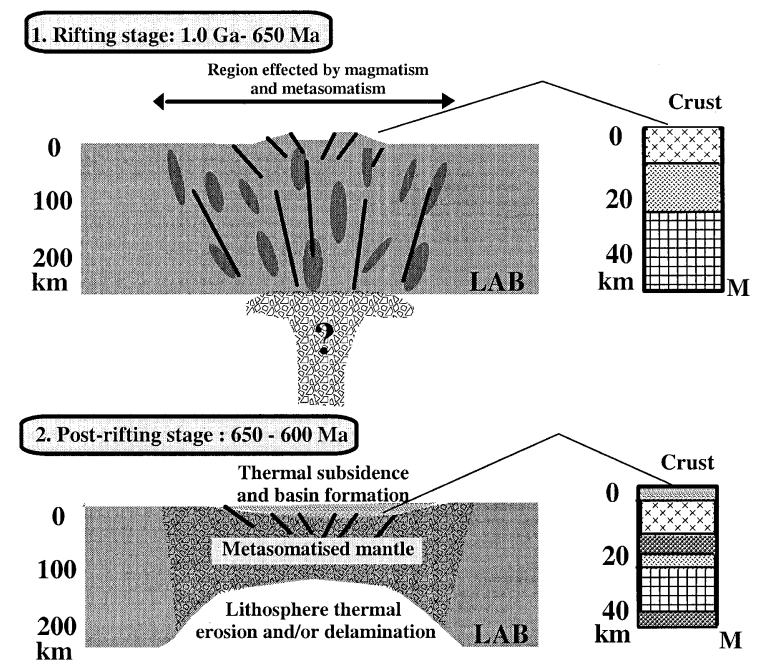

3. Platform stage: < $600 \mathrm{Ma}$

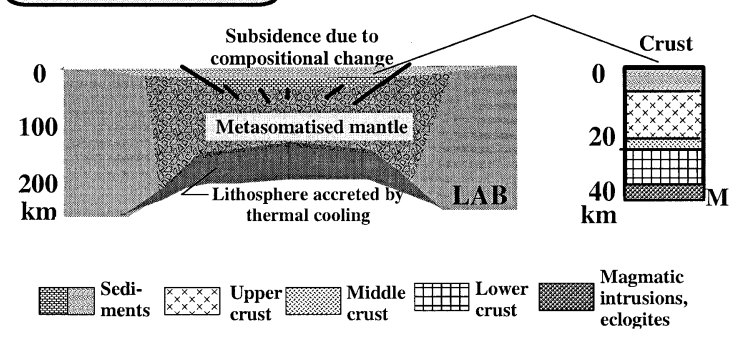

detached during late Proterozoic tectonic activity that has affected most of the platform (Fig. 5). Post-rifting lithospheric cooling should have led to lithospheric growth. If this process began already in the late Proterozoic, the lower lithosphere beneath the central part of the platform should have a composition similar to other middle-late Proterozoic regions. In this case, one can expect two compositionally distinct lithospheric layers in the central part of the Russian platform, similarly to the lithospheric mantle beneath the Slave Craton [64]. As the density deficit in the subcrustal lithosphere of the Russian platform is ca. $50 \%$ of a typical density deficit of the Archean-early Proterozoic lithosphere, one may expect a sharp compositional boundary at a depth of 90 $150 \mathrm{~km}$ (for the Archean lithosphere 180-300 km thick, as in the Baltic Shield) (Fig. 5). The boundary between the highly depleted upper layer (with high seismic velocities [59]) and more fertile lower

Fig. 5. (1) Cartoon showing reworking of the cratonic crust and the subcrustal lithosphere of the EEC during Proterozoic, presumably plume-related rifting, accompanied by intensive magmatism and metasomatic reworking of the lithosphere. Thermal cooling at the post-rifting stage (2) leads to thermal subsidence and basin formation. Magmatic intrusions accumulate at the crustal base and at the mid-crustal level, increasing the thickness of the upper crust. Ductile middle crust can be squeezed sidewards. The lower part of the lithospheric mantle (from the base up to a 100-150 km depth) is metasomatized and may be removed by thermal erosion and/or by delamination of a dense lowermost lithosphere. Further subsidence (3) is a result of fertilization of cratonic lithosphere during mantle-plume interaction and involves a much larger area than affected by rifting. This process is accompanied by an accretion of a new basal part of the lithosphere, with the fertile composition typical for late Proterozoic or Phanerozoic regions [25]. If the whole density deficit in the subcrustal lithosphere of the Russian platform (which is ca. $50 \%$ of a typical density deficit of the Archeanearly Proterozoic lithosphere) (Fig. 4a) is concentrated in its upper part, presumably unmodified by Proterozoic metasomatism, the lower half of the cratonic root has been replaced since the Proterozoic. In this case one may expect a sharp compositional boundary at a depth of ca. 90-150 km from depleted to Fe-enriched composition. This provides an alternative explanation for the $8^{\circ}$ seismic discontinuity (the top of a LVZ observed in several cratons at ca. $100 \mathrm{~km}$ depth [65]) as the base of ancient depleted lithosphere. $\mathrm{LAB}=$ lithosphere-asthenosphere boundary. 
layer (with lower velocities) can produce a seismic pattern similar to the top of a low-velocity zone (LVZ) and interpreted as the $8^{\circ}$ seismic discontinuity beneath cratons (i.e. the top of a layer at $\sim 100 \mathrm{~km}$ depth with $\sim 1 \%$ lower P-wave velocity) [65]. Late Proterozoic modification of lithospheric composition (when the lower part of the ancient depleted lithospheric mantle was replaced by younger, more fertile, and more dense material) played an ultimately important role in Paleozoic subsidence of the Russian platform, as the time gap between ceasing of rifting and platform subsidence $(\sim 50 \mathrm{Ma}[1])$ is too large to be entirely attributed to post-rifting thermal relaxation.

Paleozoic rifting had a different effect on the tectonic evolution of the southern Russian platform, including the Dnieper-Donets rift system. This region with a lithospheric thermal thickness of $120-140 \mathrm{~km}$ has less than $0.4 \%$ density deficit of the lithospheric mantle and continues to subside (Fig. 4b). Petrologic studies of peridotites from the Tanzanian and the Sino-Korean cratons $[9,26,66]$ show that Phanerozoic rifting results in vertical compositional stratification of the cratonic lithosphere due to Fe-enrichment of its lower parts by asthenospheric melts. Furthermore, xenolith data indicate removal or compositional transformation of the lower $80-140 \mathrm{~km}$ of the Archean keel in the Sino-Korean Craton and a steplike increase in fertility in the Tanzanian lithosphere at $120-150 \mathrm{~km}$ depth. Similar to Phanerozoic rifting in Tanzania and China, Devonian magmatism and metasomatic modification of the Russian platform lithosphere could have resulted in detachment and/or thermal erosion of most of the Precambrian lithospheric mantle in the southern part of the craton. If any lithospheric material has been accreted at its base since the Devonian (e.g. due to thermal cooling), it should have the fertile composition of the Phanerozoic mantle [25,67]. These conclusions are supported by the results of a joint interpretation of seismic and thermal data [68]: seismic velocities corrected for lateral temperature variations in the lithosphere suggest that the Precambrian crust of the southwestern Russian platform overlies mantle with properties similar to the mantle of western Europe. One can argue that Phanerozoic subsidence of the Peri-Caspian basin can largely be explained by an extreme compositional modification (or a detachment) of the cratonic keel in Phanerozoic (cf. Fig. 4a,b).

\section{Conclusions}

This study seeks to explain subsidence of the Russian platform by density variations in the lithospheric mantle, here hypothesized to be related to the Proterozoic and Paleozoic rifting. The thermal regime and density structure of the lithospheric mantle of the EEC are estimated to show that the Precambrian and Phanerozoic rifting had different effects on the thermal structure and lithospheric composition, and consequently on the topography of the basement rocks.

(1)Proterozoic rifting resulted in modification of the entire crustal column of the Russian platform. Regions with a thick ( $>20 \mathrm{~km}$ ) upper crust $\left(5.8<V_{\mathrm{p}}<6.4 \mathrm{~km} / \mathrm{s}\right)$ and an almost complete absence of the middle crust $\left(6.4<V_{\mathrm{p}}<6.8 \mathrm{~km} / \mathrm{s}\right)$ are spatially correlated with the craton-scale Central Russia rift system.

(2)Moho temperatures calculated from the surface heat flow data vary from $350-600^{\circ} \mathrm{C}$ in $\mathrm{Ar}$ chean-early Proterozoic terranes to $550-700^{\circ} \mathrm{C}$ in the southern parts of the Russian platform and to $600-850^{\circ} \mathrm{C}$ in middle-late Proterozoic regions of the Baltic Shield. Proterozoic rifting is not reflected in the present thermal regime of the Russian platform, where lithospheric temperature variations are not sufficiently pronounced. Thermal lithosphere of the Russian platform is $\sim 180-210$ $\mathrm{km}$ thick, with only slightly smaller values (160 $180 \mathrm{~km}$ ) along the Central Russia rift system. Paleozoic rifting, however, resulted in a pronounced lithosphere thinning (to $120-140 \mathrm{~km}$ ) in the southern parts of the Russian platform.

(3)Buoyancy-based estimates suggest a lithospheric density deficit of $\sim 1.4 \pm 0.2 \%$ for the Archean-early Proterozoic Finnish Bay-Kola-Karelian Province. A strong low-density anomaly in the Kola-Karelian Province (centered over the White Sea) correlates with seismic velocity anomalies at depths of 150-250 km [69]; a strong density anomaly in the Finnish Bay (Baltic Sea) 
correlates with seismic velocity and attenuation anomalies only down to $100-150 \mathrm{~km}$ depth, suggesting its shallow origin.

Lithospheric density deficit decreases southwards from the Baltic Shield and is $0.8 \pm 0.2 \%$ in most of the Russian platform. In the southern parts of the Russian platform, which were rifted in the Paleozoic, lithospheric density is similar to the lithospheric mantle of western Europe. Regions of less than ca. $0.4-0.6 \%$ density anomaly coincide with the area of post-Uralian subsidence, implying that compositional modification of the cratonic lithosphere caused post-Uralian subsidence of the platform.

(4)Rifting of the Russian platform has resulted in a decrease of lithospheric depletion (manifested by an increase of average lithospheric density), probably due to metasomatism. Proterozoic thermo-magmatic events might have led to formation of a two-layer lithosphere due to Fe-enrichment of its lower part. The boundary between a highly depleted upper layer and a more fertile lower layer can be at ca. $90-150 \mathrm{~km}$ depth and can produce a seismic pattern similar to the top of a seismic low-velocity layer. Paleozoic rifting had a more severe impact on the lithospheric structure of the Russian platform, leading to compositional modification and/or detachment of the entire lithospheric column, its further replacement by younger fertile material, and the consequent, on-going, subsidence of the southern Russian platform.

\section{Acknowledgements}

Thanks are due to M. Kaban, whose unpublished short-wavelength (50th degree spherical harmonics) gravity interpretation provided insights into lateral compositional heterogeneity of the European lithospheric mantle. The author is grateful to M. Ritzwoller, N. Shapiro and W. Spakman, who provided their recent seismic velocity models for Europe; these models provoked the thinking on the deep structure and vertical heterogeneities in the lithosphere of the EEC. General discussions with E.A. Bibikova and S.R. Bogdanova on the geology of the East European Craton and with S.L. Kostiuchenko and
N.I. Pavlenkova on Russian seismic data are greatly appreciated. W. Mooney has kindly provided his global compilation on the seismic structure of the crust. Special thanks are due to M. Cara for a support of the study. The comments of W. Mooney, S. Detweiler, and H. Thybo are appreciated. The reviews of R. Meissner, J.-C. Mareschal, and D. Abbott helped to improve the clarity of the presentation and are greatly acknowledged.[AC]

\section{References}

[1] A.M. Nikishin, P.A. Ziegler, R.A. Stephenson et al., Late Precambrian to Triassic history of the East European Craton dynamics of sedimentary basin formation, Tectonophysics 268 (1996) 23-63.

[2] L.I. Lobkovsky, S. Cloetingh, A.M. Nikishin et al., Extensional basins of the former Soviet Union - structure, basin formation mechanisms and subsidence history, Tectonophysics 266 (1996) 251-285.

[3] V.D. Nalivkin, Dynamics of the development of the Russian platform structures, Tectonophysics 36 (1976) 247 262.

[4] M. Gurnis, Rapid continental subsidence following the initiation and evolution of subduction, Science 255 (1992) 1556-1558.

[5] T.A. Stern, W.E. Holt, Platform subsidence behind an active subduction zone, Nature 368 (1994) 233-236.

[6] R.N. Pysklywec, J.X. Mitrovica, Mantle flow mechanisms for the large-scale subsidence of continental interiors, Geology 26 (1998) 687-690.

[7] J.X. Mitrovica, R.N. Pysklywec, C. Beaumont, A. Rutty, The Devonian to Permian sedimentation of the Russian platform; an example of subduction-controlled longwavelength tilting of continents, J. Geodyn. 22 (1996) 79-96.

[8] D. Abbott, R. Drury, W.D. Mooney, Continents as lithological icebergs: the importance of buoyant lithospheric roots, Earth Planet. Sci. Lett. 149 (1997) 15-27.

[9] C.T. Lee, R.L. Rudnick, Compositionally stratified cratonic lithosphere: petrology and geochemistry of peridotite xenoliths, in: J.J. Gurney, J.L. Gurney, M.D. Pascoe, S.H. Richardson (Eds.), Proc. 7th Int. Kimberlite Conf., Vol. 2, 1999, pp. 503-521.

[10] BABEL Working Group, Integrated seismic studies of the Baltic shield using data in the Gulf of Bothnia region, Geophys. J. Int. 112 (1993) 305-324.

[11] H. Thybo, A seismic velocity model along the EGT profile - from the North German Basin into the Baltic Shield, in: R. Freeman, P. Giese, S.T. Muller (Eds.), The European Geotraverse, Integrative Studies, European Science Foundation, Strasbourg, 1990, pp. 99-108. 
[12] U. Luosto, Crustal structures of eastern Fennoscandia, Tectonophysics 189 (1991) 19-27.

[13] P. Sroda, W. Czuba, A. Guterch et al., P- and S-wave velocity model of the southwestern margin of the Precambrian East European Craton; POLONAISE '97, Profile P3, Tectonophysics 314 (1999) 175-192.

[14] EUROBRIDGE Working Group, EUROBRIDGE'95; deep seismic profiling within the East European Craton, Tectonophysics 339 (2001) 153-175.

[15] R.G. Garetskii, A.M. Boborykin, V.A. Bogino, V.A. German, S.A. Veres, S.V. Klushin, V.G. Shafaruk, Deep seismic sounding on the territory of Belorussia, Geophys. J. Int. 8 (1990) 439-448.

[16] V.B. Sollogub, The Lithosphere of the Ukraine, Naukova Dumka, Kiev, 1986, 187 pp.

[17] M. Grad, A. Tripolsky, Crustal structure from P and S seismic waves and petrological model of the Ukrainian shield, Tectonophysics 250 (1995) 89-112.

[18] V.V. Beloussov, N.I. Pavlenkova, G.N. Kvyatkovskaya (Eds.), Structure of the Crust and Upper Mantle of the [Former] USSR, Int. Geol. Rev. 34, No. 3, Winston, Silver Spring, MD, 1992, 219 pp.

[19] S.M. Zverev, I.P. Kosminskaya, Seismic models of the lithosphere for the major geostructures on the territory of the USSR, Nauka, Moscow, 1980, 184 pp.

[20] W.D. Mooney, C. Prodehl, N.I. Pavlenkova, Seismic velocity structure of the continenal lithosphere from controlled source data, in: H. Kanamori, P. Jennings, W.H.K. Lee (Eds.), IASPEI Handbook on Earthquake and Engineering Seismology, 2002, in press.

[21] R. Gorbatschev, S. Bogdanova, Frontiers in the Baltic Shield, Precambrian Res. 64 (1993) 3-21.

[22] D. Abbott, W.D. Mooney, The structural, geochemical evolution of the continental crust: Support for the oceanic plateau model of continental growth, Rev. Geophys. Suppl. (1995) 231-242.

[23] R.L. Rudnick, Making continental crust, Nature 378 (1995) 571-578.

[24] S.L. Kostyuchenko, A.V. Egorkin, L.N. Solodilov, Structure and genetic mechanisms of the Precambrian rifts of the East-European Platform in Russia by integrated study of seismic, gravity and magnetic data, Tectonophysics 313 (1999) 9-28.

[25] W.L. Griffin, S.Y. O'Reilly, C.G. Ryan, O. Gaul, D. Ionov, Secular variation in the composition of subcontinental lithospheric mantle, in: J. Braun et al. (Ed.), Structure and Evolution of the Australian Continent, AGU Geodynam. Ser. 26 (1998) 1-25.

[26] X. Xu, S.Y. O'Reilly, W.L. Griffin, X. Zhou, Genesis of young lithospheric mantle in southeastern China; an LAM-ICPMS trace element study, J. Petrol. 41 (2000) 111-148.

[27] V. Cermak, Geothermal model of the lithosphere and the map of the lithosphere thickness for the USSR territory, Izv. AN SSSR Fiz. Zemli 11 (1982) 25-38.

[28] V. Cermak, Lithosperic thermal regimes in Europe, Phys. Earth Planet. Inter. 79 (1993) 179-193.
[29] I.M. Artemieva, W.D. Mooney, Thermal thickness and evolution of Precambrian lithosphere: A global study, J. Geophys. Res. 106 (2001) 16387-16414.

[30] N. Balling, Heat flow and thermal structure of the lithosphere across the Baltic Shield and northern Tornquist Zone, Tectonophysics 244 (1995) 13-50.

[31] I.T. Kukkonen, P. Peltonen, Xenolith-controlled geotherm for the central Fennoscandian Shield: Implications for lithosphere-asthenosphere relations, Tectonophysics 304 (1999) 301-315.

[32] V. Pasquale, M. Verdoya, P. Chiozzi, Heat flux and seismicity in the Fennoscandian Shield, Phys. Earth Planet. Inter. 126 (2001) 147-162.

[33] R.I. Kutas, V.A. Tsviaschenko, I.N. Korchagin, Modelling Thermal Field of the Continental Lithosphere, Naukova Dumka, Kiev, 1989, 191 pp.

[34] V. Cermak, J. Safanda, A. Guterch, Deep temperature distribution along three profiles crossing the TeisseyreTornquist tectonic zone in Poland, Tectonophysics 164 (1989) 151-163.

[35] V.V. Gordienko, O.V. Zavgorodnyaya, Thermal field of the south-eastern part of the Russian platform, Geophysical J. 6(6) (1985) 801-814, translation by Gordon and Breach, New York.

[36] H.N. Pollack, S.J. Hurter, J.R. Johnson, Heat flow from the Earth's interior: analysis of the global data set, Rev. Geophys. 31 (1993) 267-280.

[37] Swedish geothermal resources borehole data summary, unpublished report, 1994.

[38] I.T. Kukkonen, Vertical variation of apparent and paleoclimatically corrected heat flow densities in the Central Baltic Shield, J. Geodyn. 8 (1987) 33-54.

[39] A.A. Nyblade, H.N. Pollack, A global analysis of heat flow from Precambrian terrains: Implications for the thermal structure of Archean and Proterozoic lithosphere, J. Geophys. Res. 98 (1993) 12207-12218.

[40] R.I. Kutas, Geothermal model of the crust of the Ukrainian Shield, in: V. Cermak, L. Rybach (Eds.), Terrestrial Heat Flow in Europe, Springer, Berlin, 1979, 269 304.

[41] A.A. Smyslov, U.I. Moiseenko, T.Z. Chadovich, Thermal Regime and Radioactivity of the Earth, Leningrad, Nedra, 1979, $191 \mathrm{pp}$.

[42] C. Jaupart, J.-C. Mareschal, The thermal structure and thickness of continental roots, Lithos 48 (1999) 93-114.

[43] N.M. Shapiro, M.H. Ritzwoller, Monte-Carlo inversion for a global shear velocity model of the crust and upper mantle, Geophys. J. Int. 51 (2002) 267-280.

[44] W.L. Griffin, C.G. Ryan, F.V. Kaminsky, S.Y. O'Reilly, L.M. Natapov, T.T. Win, P.D. Kinny, I.P. Ilupin, The Siberian lithosphere traverse: mantle terranes and the assembly of the Siberian Craton, Tectonophysics 310 (1999) $1-35$.

[45] A.H. Lachenbruch, P. Morgan, Continental extension, magmatism and elevation; formal relations and rules of thumb, Tectonophysics 174 (1990) 39-62.

[46] W.D. Mooney, G. Laske, T.G. Masters, CRUST 5.1: A 
global crustal model at $5^{\circ} \times 5^{\circ}$, J. Geophys. Res. 103 (1998) 727-747.

[47] ETOPO2: Global 2-minute gridded elevation data compilation of the National Geophysical Data Center, Boulder, Colorado, http://www.ngdc.noaa.gov.

[48] Y.H. PoudjomDjomani, S.Y. O'Reilly, W.L. Griffin, P. Morgan, The density structure of subcontinental lithosphere through time, Earth Planet. Sci. Lett. 184 (2001) 605-621.

[49] M.K. Kaban, P. Schwintzer, I.M. Artemieva, W.D. Mooney, Density of the continental roots: compositional and thermal effects, Earth Planet Sci. Lett. 209 (2003) 5369.

[50] C. Lithgow-Bertelloni, P.G. Silver, Dynamic topography, plate driving forces and the African superswell, Nature 395 (1998) 269-272.

[51] C.J. Hawkesworth, P.D. Kempton, N.W. Rogers, R.M. Ellam, P.W. van Calsteren, Continental mantle lithosphere, and shallow level enrichment process in the Earth's mantle, Earth Planet. Sci. Lett. 96 (1990) 256-268.

[52] F.R. Boyd, Compositional distinction between oceanic and cratonic lithosphere, Earth Planet. Sci. Lett. 96 (1989) 15-26.

[53] W.D. Mooney, J. Vidale, Isostatic evidence for thermal and chemical variations in cratonic lithosphere, in: A. Jones (Ed.), Multidisciplinary Studies of Kaapvaal and Slave Cratons, Lithos Spec. Vol. (2003) in press.

[54] F.R. Boyd, D.G. Pearson, S.A. Mertzman, Spinet-facies peridotites from the Kaapvaal root, in: J.J. Gurney, J.L. Gurney, M.D. Pascoe, S.H. Richardson (Eds.), Proc. 7th Int. Kimberlite Conf., 1999, Vol. 1, pp. 40-48.

[55] W.L. Griffin, S.Y. O'Reilly, C.G. Ryan, The composition and origin of subcontinental lithospheric mantle, in: Y. Fei, C.M. Bertka, B.O. Mysen (Eds.), Mantle Petrology: Field Observations and High Pressure Experimentation: A Tribute to Francis R. (Joe) Boyd, Geochem. Soc. Spec. Publ. 6 (1999) 13-45.

[56] J.X. Mitrovica, W.R. Peltier, The inference of mantle viscosity from an inversion of the Fennoscandian relaxation spectrum, Geophys. J. Int. 114 (1993) 45-62.

[57] S.-I. Karato, B.B. Karki, Origin of lateral variation of seismic wave velocities and density in the deep mantle, J. Geophys. Res. 106 (2001) 21771-21783.

[58] A.M. Forte, A.C. Perry, Seismic-geodynamic evidence for a chemically depleted continental tectosphere, Science 290 (2000) 1940-1944.
[59] F. Deschamps, J. Trampert, R. Snieder, Anomalies of temperature and iron in the uppermost mantle inferred from gravity data and tomographic models, Phys. Earth Planet. Inter. 129 (2002) 245-264.

[60] M. Billien, J.-J. Lévêque, J. Trampert, Global maps of Rayleigh wave attenuation for periods between 40 and 150 seconds, Geophys. Res. Lett. 27 (2000) 3619-3622.

[61] T.H. Jordan, Structure and formation of the continental tectosphere, J. Petrol, Spec. Lithosphere Issue (1988) 1137.

[62] R.T. vanBalen, M. Heermans, Middle Proterozoic - early Palaeozoic evolution of central Baltoscandian intracratonic basins: evidence for asthenospheric diapirs, Tectonophysics 300 (1998) 131-142.

[63] O.F. Gaul, W.L. Griffin, S.Y. O'Reilly, N.J. Pearson, Mapping olivine composition in the lithospheric mantle, Earth Planet. Sci. Lett. 182 (2000) 223-235.

[64] W.L. Griffin, B.J. Doyle, C.G. Ryan, N.J. Pearson, S.Y. O'Reilly, R. Davies, K. Kivi, E. vanAchterbergh, L.M. Natapov, Layered mantle lithosphere in the Lac de Gras area, Slave craton: composition, structure and origin, J. Petrol. 40 (1999) 705-727.

[65] H. Thybo, E. Perchuc, The seismic $8^{\circ}$ discontinuity and partial melting in continental mantle, Science 275 (1997) 1626-1629.

[66] W.L. Griffin, A. Zhang, S.Y. O'Reilly, C.G. Ryan, Phanerozoic evolution of the lithosphere beneath the Sino-Korean craton, in: M.F.J. Flower, S.L. Chung, C.H. Lo, T.Y. Lee (Eds.), Mantle Dynamics and Plate Interactions in East Asia, AGU Geodynam. Ser. 27 (1998) 107-126.

[67] J. DeSmet, A.P. vandenBerg, N.J. Vlaar, Early formation and long-term stability of continents resulting from decompression melting in a convecting mantle, Tectonophysics 322 (2000) 19-33.

[68] I.M. Artemieva, W.D. Mooney, M.A. Krasnova, Are the cratonic margins vertical? The case study of the TESZ from thermal and seismic data, EGS Geophys. Res. Abstr., Vol. 4, 2002.

[69] W. Spakman, Delay-time tomography of the upper mantle below Europe, the Mediterranean, and Asia Minor, Geophys. J. Int. 107 (1991) 309-332.

[70] S.-̊. Elming, N.P. Mikhailova, S. Kravchenko, Palaeomagnetism of Proterozoic rocks from the Ukrainian Shield: new tectonic reconstructions of the Ukrainian and Fennoscandian shields, Tectonophysics 339 (2001) 19-38. 